
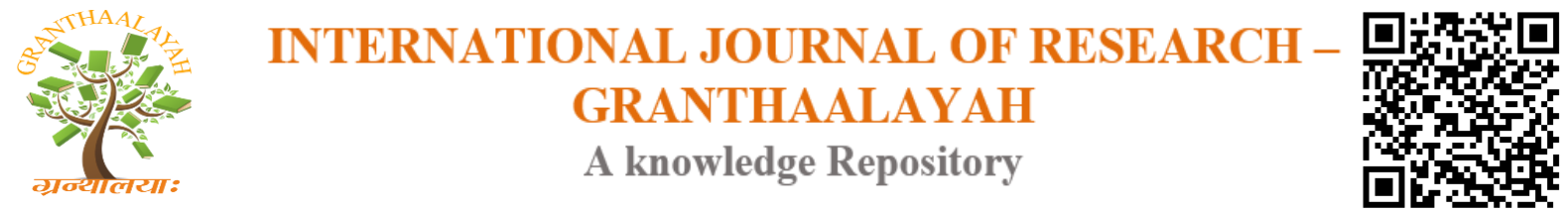

Management

\title{
CELEBRITY ENDORSEMENT AND BUYING BEHAVIOR: A STUDY OF PANJAB UNIVERSITY STUDENTS
}

\author{
Supreet Kaur ${ }^{1}$, Ankit Garg ${ }^{2}$ \\ ${ }^{1}$ Research Scholar, Department of Commerce, Punjabi University, Patiala, INDIA \\ ${ }^{2}$ Research Scholar, University School of Applied Management, Punjabi University, Patiala,
} INDIA

DOI: https://doi.org/10.29121/granthaalayah.v4.i11.2016.2430

\section{ABSTRACT}

In present era, there has been a change in consumer's attitude towards lifestyle. Consumers give importance to brands to ensure better standard of living. Today consumers are not only educated but also selective while purchasing products. Everyday consumers are exposed to number of voices over the radio and $T V$ and images in newspapers, magazines, hoardings, and websites. Therefore, every marketer tries to steal at least fraction of a person's time to inform him/her of the amazing and different attributes of the product at hand and for this purpose marketers use celebrity endorsement as an effective marketing strategy to fit their products in the minds of consumers. The practice of celebrity endorsements has proliferated over time and perceived as a winning formula for product marketing and brand building. This paper is an effort to analyze the impact of celebrity endorsements on buying behaviour of the college students. Questionnaire survey was used to collect the data by using convenience sampling.

Keywords:

Attractiveness, Buying Behaviour, Celebrity Endorsers, Multiple endorsements.

Cite This Article: Supreet Kaur, and Ankit Garg, "CELEBRITY ENDORSEMENT AND BUYING BEHAVIOR: A STUDY OF PANJAB UNIVERSITY STUDENTS" International Journal of Research - Granthaalayah, Vol. 4, No. 11 (2016): 122-136.

\section{INTRODUCTION}

Our market is flooded with different number of brands trying to carve out space for itself in the minds of consumers. Every firm is trying to find a hook in their brands that can connect faster to the viewers. Therefore, the challenge before the marketer is to induct all possible measures to influence, motivate and inculcate desire to purchase, in the customer through an effective advertising campaign. In order to achieve this, use of celebrity for endorsement of a brand is widely used marketing strategy. Celebrity endorsement has become a pervasive element of multi billionaire advertising industry. Companies invest large sums of money to align their brands and themselves with endorsers. Such endorsers are seen as dynamic with both attractive and likeable 
qualities and companies plan that these qualities are transferred to products via marketing communications activities. Furthermore, because of their fame, celebrities serve not only to create and maintain attention, but also to achieve high recall rates for marketing communication messages in today's highly cluttered environments. Thus, celebrity endorsement in advertisement and its impact on the overall brand is of great significance. In this process, the companies hire celebrities such as from a particular field (Sports, TV Stars, and Models) to feature in its advertisement campaigns. Products ranging from a notebook to electronics use celebrities for communication. Ad Ex India Report, 2007 reported that a top celebrity can get as many as 21 advertisers to endorse products. Various companies are signing deals with celebrities in the hope that by using celebrities they can accomplish a unique and relevant position in the minds of the consumers. Celebrity endorsement is increasingly being employed across various industries regardless of the product type. It is known to be playing the role of a signaling strategy.

According to TAM Universe Update 2015, there are around $277 \mathrm{mn}$ viewers of TV which means that an effective ad campaign can influence such a large number of people. Marketers try to penetrate such a large number of populations by creating a loophole that can best fit in the minds of consumers. Celebrity Endorsements enhances the volume of sales of a brand and expedite the brand recall rate of advertisements that helps firms in creating a niche in the market. Effective celebrity endorsers grab the eyeballs of the existing and potential customers and arouse the interest by attaining the attention of customers.

\section{CELEBRITY}

A Celebrity is a person, who has a prominent profile and commands some degree of public fascination and influence in day-to-day media. A Person with great popular appeal, prominence in a particular field, and is easily recognized by the general public. Various careers within the fields of sports and entertainment are commonly associated with celebrity status. While people may gain celebrity status as a result of a successful career in a particular field (primarily in the areas pertaining towards sports and entertainment), in other cases, people become celebrities due to media attention for their extravagant lifestyle or wealth (as in the case of a socialite); for their connection to a famous person (as in the case of a relative of a famous person); or even for their misdeeds (as in the case of a well-known criminal). Celebrities may be known around the world (e.g., pop stars and film actors), within a specific country (e.g., a top Australian rugby player); or within a region (e.g., a local television news anchor). According to Friedman and Friedman, a "celebrity endorser is an individual who is known by the public for his or her achievements in areas other than that of the product class endorsed". Compared to other endorser types, famous people always attach a greater degree of attention, recall and loyalty. In this age of intense competition, where capturing a position in the consumers' mind space is extremely tough, celebrity endorsements give an extra edge to the companies for holding the viewers' attention. Celebrities can catalyze brand acceptance and provide the enormous momentum that brands require by endorsing the intrinsic value to the brand.

\section{CELEBRITY ENDORSEMENT}

A form of brand or advertising campaign that involves a well-known person using his/her fame to help promote a product or service. It refers to use of celebrities in order to increase sales of a 
product. Celebrity Endorsement was initiated mid 80's in India. One of the first sports endorsements in India was when Farokh Engineer became the first Indian Cricketer to model for Brylcream. The Indian cricket team now earns roughly Rs. 100 crore through endorsements. There is a spurt of advertising, featuring stars as tabassum (Prestige Pressure cookers), Jalal Agha (Pan Parag), Kapil Dev (Palmolive Shaving cream) and Sunil Gavaskar(Dinesh Sutings) to now days Aishwarya Rai (Olay Cream), Kajol (Alpenlibe), Shahrukh (Navratan Cool Talc) \& Aamir Khan (Godrej) \& many more.

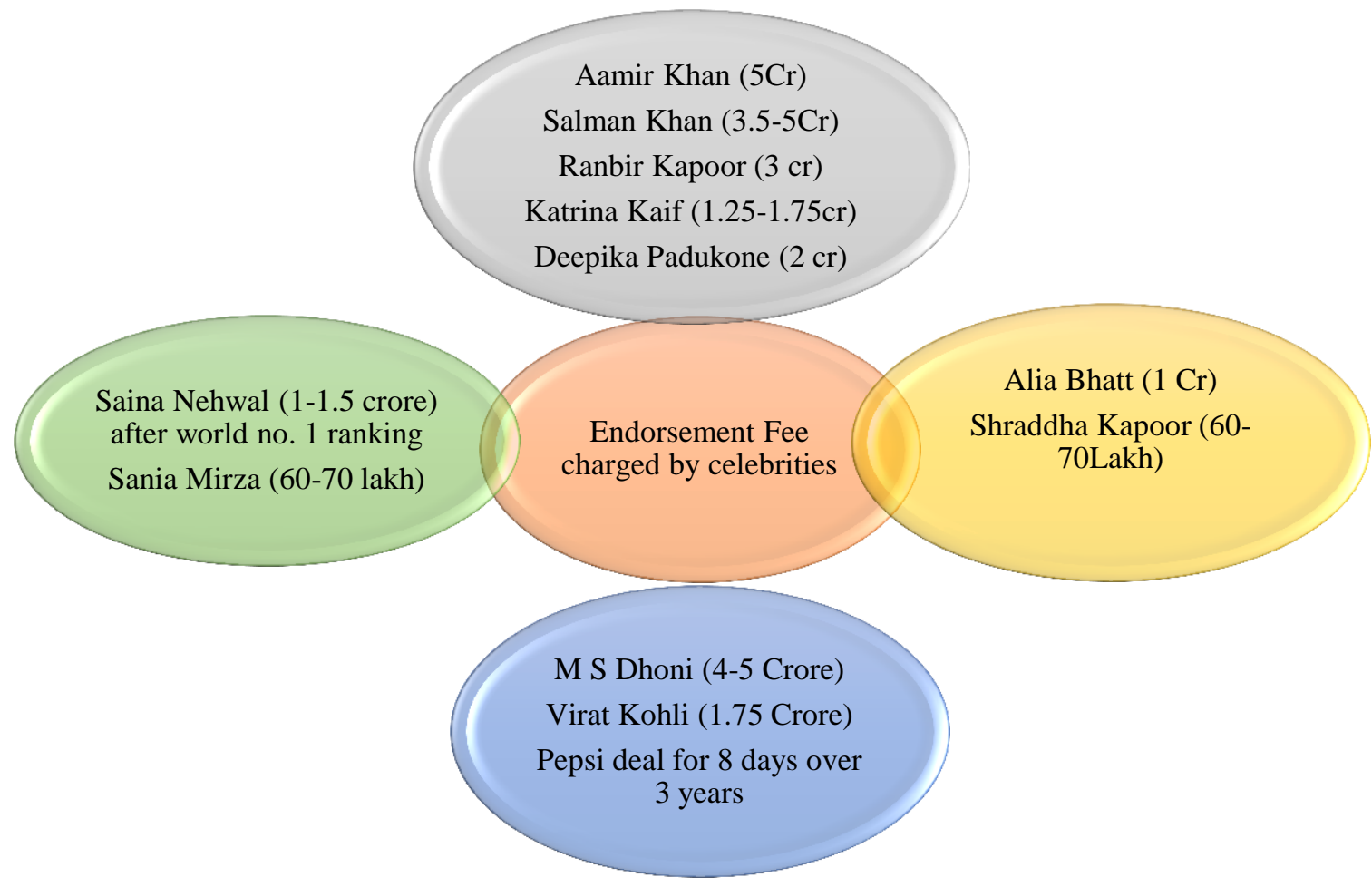

Source: Economic Times (April'15)

TOP 10 ACTORS AND ACTRESS IN SEP'15

\begin{tabular}{|llllll|}
\hline Rank & Actor & T Score & Rank & Actress & T Score \\
\hline $\mathbf{1}$ & Salman Khan & 26.0 & 1 & Kareena Kapoor & 22.5 \\
\hline $\mathbf{3}$ & Shahrukh Khan & 20.0 & 2 & Priyanka Chopra & 22.0 \\
\hline $\mathbf{4}$ & Ranbir Kapoor & 19.0 & 3 & Anushka Sharma & 21.5 \\
\hline $\mathbf{5}$ & Saif Ali Khan & 18.7 & 4 & Katrina Kaif & 20.0 \\
\hline $\mathbf{6}$ & Akshay Kuman & 18.5 & 5 & Shraddha Kapoor & 19.0 \\
\hline $\mathbf{7}$ & John Abraham & 17.0 & 6 & Alia Bhatt & 18.5 \\
\hline $\mathbf{8}$ & Amitabh Bachchan & 16.0 & 7 & Kangana Ranaut & 17.5 \\
\hline $\mathbf{9}$ & Varun Dhawan & 15.0 & 8 & Yami Gautam & 17.0 \\
\hline $\mathbf{1 0}$ & Farhan Akhtar & 13.5 & 9 & Deepika Padukone & 16.0 \\
\hline S & 12.5 & 10 & Aishwarya Rai & 13.0 \\
\hline
\end{tabular}

Source: Timescelebex (September'2015) 
Key Determinants of $\mathbf{T}$ Score are:

- Box office returns and recognition

- Ability to stay in news across print and TV

- Visibility through endorsements on print and TV

- Promotions of their upcoming movie release on print and TV

- Popularity among fans across mediums including the internet and social media

HIGHEST EARNING CELEBRITIES - FORBES CELEBRITY 2015

\begin{tabular}{|lll|}
\hline Rank & Celebrity & $\begin{array}{l}\text { Earnings } \\
\text { (including } \\
\text { endorsements) }\end{array}$ \\
\hline $\mathbf{1}$ & SALMAN KHAN & 244 CRORE \\
\hline $\mathbf{2}$ & SHAHRUKH KHAN & 203 CRORE \\
\hline $\mathbf{3}$ & AMITABH BACHCHAN & 196 CRORE \\
\hline $\mathbf{4}$ & AKSHAY KUMAR & 172 CRORE \\
\hline $\mathbf{5}$ & MS DHONI & 142 CRORE \\
\hline $\mathbf{6}$ & RANBIR KAPOOR & 93 CRORE \\
\hline $\mathbf{7}$ & HRITHIK ROSHAN & 85 CRORE \\
\hline $\mathbf{8}$ & AAMIR KHAN & 81 CRORE \\
\hline $\mathbf{9}$ & DEEPIKA PADUKONE & 67 CRORE \\
\hline $\mathbf{1 0}$ & SAIF ALI KHAN & 63 CRORE \\
\hline
\end{tabular}

Source: Forbes India

Snapdeal recently signed up Aamir Khan for Rs 30 crore while Rasna got Akshay Kumar on board for Rs 18 crore in a three-year deal.

HIGHEST-PAID ATHLETE ENDORSERS OF 2015

\begin{tabular}{|c|c|c|c|}
\hline RANK & SPORTS PERSON & $\begin{array}{l}\text { YEARLY } \\
\text { ENDORSEMENT } \\
\text { EARNINGS }\end{array}$ & NOTABLE DEALS \\
\hline 1. & ROGER FEDERER & $\$ 5,80,00,000$ & $\begin{array}{l}\text { Wilson, Nike, Rolex, } \\
\text { Mercedes-Benz, Gillette }\end{array}$ \\
\hline 2. & TIGER WOODS & $\$ 5,00,00,000$ & Nike, Upper Deck, Rolex \\
\hline 6. & RORY MCILROY & $\$ 3,20,00,000$ & $\begin{array}{c}\text { Nike, Bose, EA Sports, } \\
\text { Omega, Upper Deck }\end{array}$ \\
\hline 7. & NOVAK DJOKOVIC & $\$ 3,10,00,000$ & Adidas, Mercedes-Benz \\
\hline 8. & RAFAEL NADAL & $\$ 2,80,00,000$ & $\begin{array}{c}\text { Tommy Hilfiger, Kia, Nike, } \\
\text { Bacardi }\end{array}$ \\
\hline 9. & CRISTIANO RONALDO & $\$ 2,70,00,000$ & Tag heuer, Samsung \\
\hline 10. & MS DHONI & $\$ 2,70,00,000$ & $\begin{array}{c}\text { PepsiCo, Aircel, Godrej, } \\
\text { Gulf Oil, Reebok }\end{array}$ \\
\hline 13. & LIONEL MESSI & $\$ 2,20,00,000$ & $\begin{array}{c}\text { Adidas, EA Sports, Gillette, } \\
\text { Head \& Shoulders }\end{array}$ \\
\hline
\end{tabular}

Source: Opendorse 
Dhoni's total earnings stood at USD 31 million, including amount from salary/winnings at USD 4 million and endorsements worth USD 27 million.

OVERALL MOST MARKETABLE CELEBRITY ENDORSERS-2015

\begin{tabular}{|llll|}
\hline Rank & Endorser & $\begin{array}{l}\text { Endorser's } \\
\text { Likeability }(\%)\end{array}$ & $\begin{array}{l}\text { Brand Memorability } \\
\text { Index }\end{array}$ \\
\hline $\mathbf{1}$ & Liam Neeson & 78 & 208 \\
\hline $\mathbf{2}$ & Pierce Brosnan & 75 & 104 \\
\hline $\mathbf{3}$ & Matthew Mcconaughey & 74 & 164 \\
\hline $\mathbf{4}$ & Jennifer Garner & 72 & 148 \\
\hline $\mathbf{5}$ & Natalie Portman & 71 & 160 \\
\hline $\mathbf{6}$ & Jeff Bridges & 71 & 152 \\
\hline $\mathbf{7}$ & Sofia Vergara & 71 & 120 \\
\hline $\mathbf{8}$ & Jim Parsons & 69 & 172 \\
\hline $\mathbf{9}$ & Dennis Haysbert & 69 & 160 \\
\hline $\mathbf{1 0}$ & J K Simmons & 69 & 108 \\
\hline
\end{tabular}

Source: Nielson Survey'15

\section{REVIEW OF LITERATURE}

Giridhar (2012) study analyzed the factors that motivate and affect the purchase attitude of consumers at Shimoga and also studied the consumer perception on endorsement of celebrities through advertisement. Data has been collected with the help of structured questionnaire from 50 respondents by using convenience sampling. The study found that celebrity endorsement enhances product information and creates awareness among consumers. It helps them to recall the brands of the endorsed products. It also revealed that the celebrities convincing endorsement motivates them to materialize the purchase of durables. Boopathy \& Chaudhari (2013) showed the impact generated in the minds of customers due to advertisements featuring celebrity, the impact of the children generated in the buying behavior of parents and the means through which children attack the mindset of parents. The study uses a standard questionnaire to collect the data from the samples. The paper used the samples from the family in which both the parents are working. Convenient sampling method is used to pull out members for the study. A sample of 50 is used for the research. The analysis were done by using statistical tools like Correlation \& Regression; Hypothesis Testing: $\mathrm{t}$ - test; Ranking Technique - Weighted Average Method. The findings revealed that children are more impacted through advertisement that features celebrity in it. In this case, there is a significantly higher level of impact of celebrity endorsed advertisements in children than in parents. Naresh \& Latha (2014) assessed the impact of attitude of the consumers towards celebrity endorsement of Telecom Brands purchasing. The sample respondents were recruited using random sampling. The method for sample selection was Systematic random sampling. A self-completion questionnaire was administered to respondents for their responses towards the queries in three Districts: Chittoor, Nellore, Kadapa. Survey brands included four product brands produced by Indian Telecom service Providers namely Vodafone, Aircel, Reliance Communication and Idea. The most important finding of the study is that celebrity endorsement is effective for marketing communication. The study also revealed that young consumers (students) got influenced by celebrity endorsement strategy on their purchase decision. Age of the respondents plays a key role supposing to host a positive or 
negative attitude towards celebrity endorsement. Pugazhenthi (2014) examined the impact of celebrity endorsement on the brand image perception and attitude of college students. This study was conducted in Coimbatore City and is focused on the college students. Respondents include undergraduates and postgraduates of almost all disciplines. 1200 samples were collected from the college students of Coimbatore region based on one-to-one survey. The study revealed that the purchase behaviour of college students could differ based on their life style. Demographic attributes of the students are expected to affect their purchase behavior, which in turn is expected to affect their attitude towards celebrity endorsement in general. The results of the study revealed that there exists strong association between gender and price consciousness. Gender and age of the college students attributed to the quality consciousness behavior. Age and current status of the youth affect the importance given by them to the social values. Randhawa \& Khan (2014) examined the consumer perception on celebrity endorsement of FMCG Products and the impact of change in brand endorser on product image. For this purpose the data was collected with the help of pre structured questionnaire through convenience sampling from 50 respondents, percentage method is used to analyze the data. The results showed that celebrity endorsement enhances product information and creates awareness among consumers. It helps them to recall the brands of the endorsed products. Celebrity Endorsed Ads persuade customers to purchase products rather than non-celebrity endorsed Ads, Comic character Ads, Executive Ads and Fiction Ads. Most of the respondents believe that frequent changes in celebrity for advertising the product reduce the purchasing decision of customers. Patel (2015) examined consumer attitude towards celebrity endorsement with special reference to film stars versus sports star as Celebrity Endorser. The study surveyed 711 respondents i.e. MBA/MCA students of south Gujarat region with regard to their attitude towards celebrity Endorsement. Data were collected from both primary as well as secondary sources. Primary data were collected through a structured questionnaire. The findings showed that there is no difference in consumer's perception about credibility of Celebrity based on type of Celebrity i.e. whether it is Film stars or Sports stars and there is a difference in consumers' attitude towards Celebrity Endorsement based on gender.

\section{RESEARCH OBJECTIVES}

- To analyze whether advertising campaigns using celebrities increase the recall rate of advertisement.

- To assess which sort of celebrity influences the most to the buyer's purchasing intentions.

- To find whether products and services endorsed by celebrities enhances brand image of the product endorsed.

- To find whether celebrity endorsement influences purchasing intentions of the students.

\section{NEED OF THE STUDY}

Marketers spend a number of amounts in order to rope in top notched celebrity so as to allure the customers. As per the census of India 2011, the size of student's population has seen a slightly increase with over 315 million students in the country. It is obvious from the facts that youth market is a very potential market and is perceived as a difficult one to tap. Youngsters are more exposed to internet and other Medias; therefore they compare each thing while making a purchase. Youngsters reject all marketing messages that lack credibility. They are educated and 
picky about the products they use. This paper has tried to analyze the viewpoints of college going students with regards to celebrity endorsements. In this study factors affecting purchasing intentions of customers have been analyzed.

\section{SIGNIFICANCE OF THE STUDY}

Celebrities add flavor to the advertisement campaigns and make them colorful attracting the eyeballs of the millions. It refreshes the brand image and helps in quick brand recognition. Association of a brand with a highly noted celeb can make it more attractive. The influence of the celebrity image and its effect on the younger generations has been an issue for quite some time. Thus, the current study attempts to analyze the impact of celebrity appeal on purchase intention of college going youth. The current study will provide a clear understanding of the above discussed concept. The study will be helpful for advertising practitioners, marketers, researchers and academicians in inferring the impact of celebrity endorsement on youth and thereby will help in penetrating the market more effectively.

\section{RESEARCH METHODOLOGY}

The study entitled, "Celebrity endorsement and buying behaviour: A study of college students" is focused mainly on assessing the view points from students of Panjab University about how celebrity endorsements affect their purchasing decisions. This study is based on descriptive research as perception of college students regarding celebrity endorsement is analyzed and its impact over the purchase intention is measured. The present study has equal contribution of both primary and secondary data. Secondary data is collected through data collection from the internet, from review of existing literatures, newspapers, journals and magazines and research theses whereas primary research was carried out with the help of a well-structured questionnaire and likert scales were used for scaling the questions.

Sample size: Present study has a sample size of 50 students from University Business School of Panjab University.

Sampling technique: For the present study, convenience sampling was used to choose respondents.

Statistical tools: For the present study, Percentage method is used to analyze the data.

\section{ANALYSES \& INTERPRETATION OF DATA}

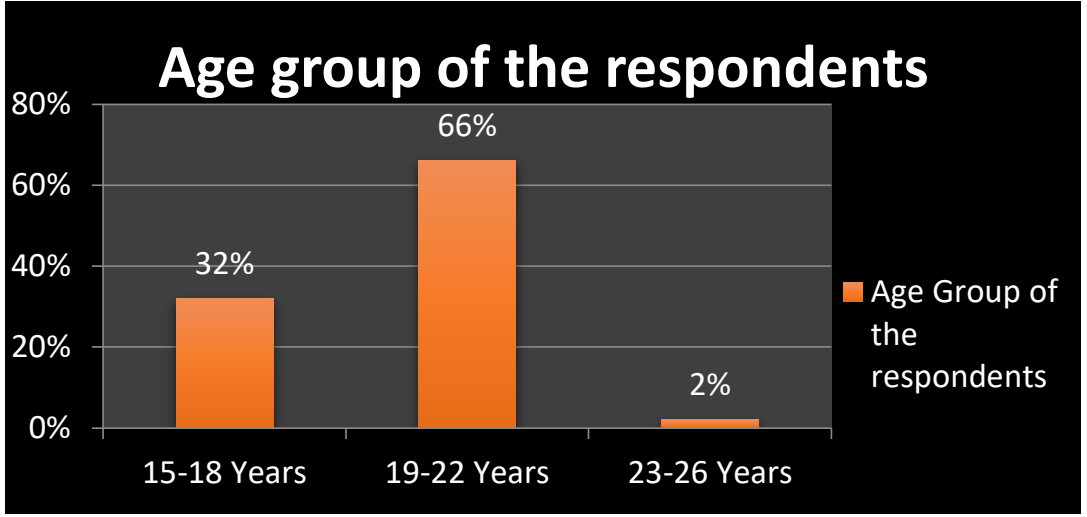

Source: Field Survey

Figure 1: 
From the above figure it can be seen that $66 \%$ of the respondents fall within the age group of 1922 years and $32 \%$ of the respondents fall in the age group of $15-18$ years whereas only $2 \%$ of the respondents fall within the age group of 23-26 years. Hence it shows that the data represents mainly the viewpoints of young generation.

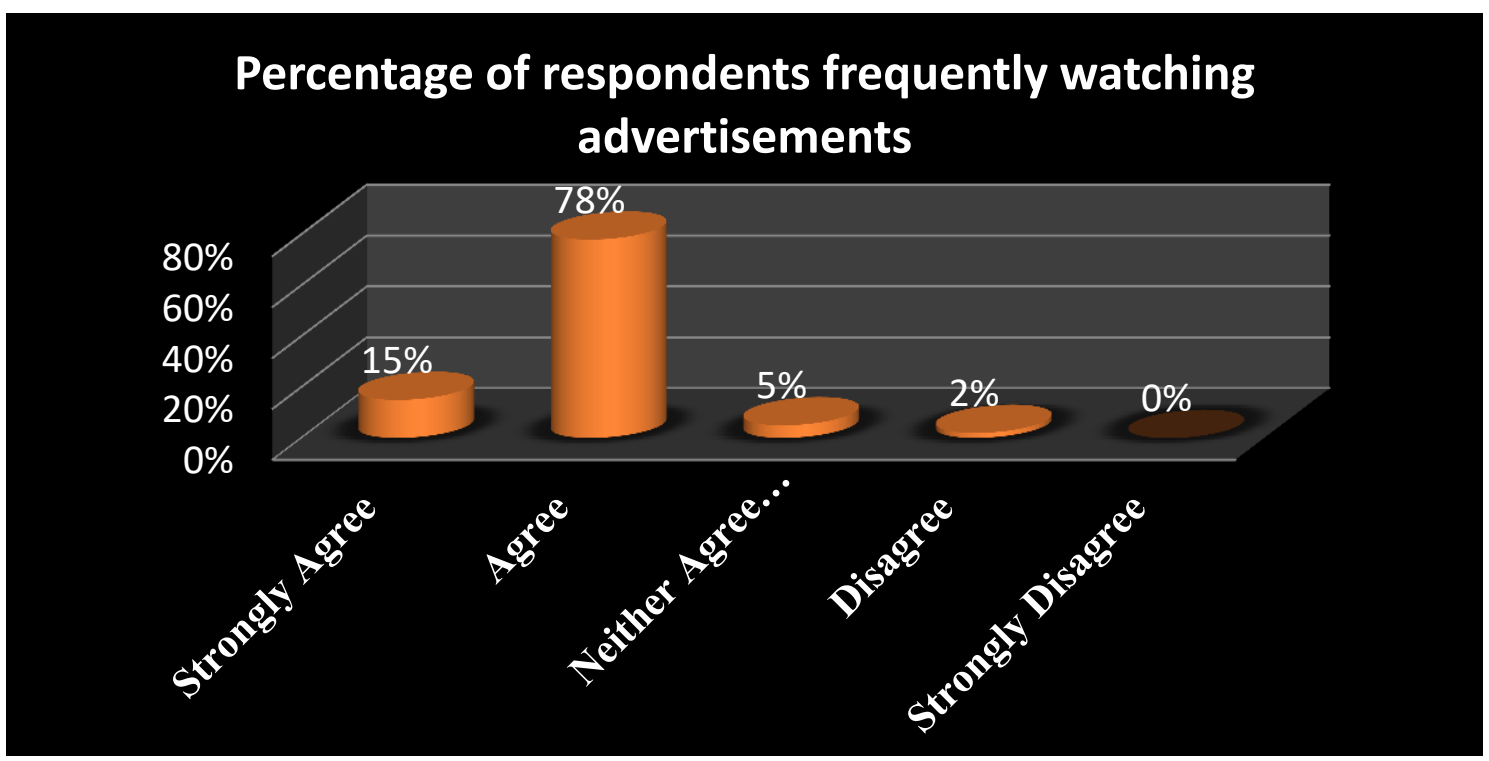

Figure 2:

Source: Field Survey

It can be concluded from the above figure that there are around $78 \%$ of the respondents who agree that they watch advertisements on regular basis while $15 \%$ strongly agree that they watch advertisements frequently and persons not watching advertisements frequently constitute merely $2 \%$ of the respondents which shows respondents at a larger scale pay attention to the products advertised on various media.

Table 1: Most Influencing vehicle of media

\begin{tabular}{|ll|}
\hline Rank & Factor \\
\hline $\mathbf{1}$ (Most Influencing) & TV \\
\hline $\mathbf{2}$ & Internet \\
\hline $\mathbf{3}$ & Newspaper \\
\hline $\mathbf{4}$ & Magazine \\
\hline $\mathbf{5}$ & Radio \\
\hline $\mathbf{6}$ (Least Influencing) & Hoardings \\
\hline
\end{tabular}

Source: Field Survey

The above ranks have been computed by using the likert scale. It has been found while personal investigation that larger people were having more access to the TV as compared to the other sources and that is why they have ranked TV as most influencing media of vehicle. 
Table 2:

\begin{tabular}{|ll|}
\hline RANKS & FACTOR INFLUENCING PURCHASING DECISION \\
\hline $\mathbf{1}$ (Most Influencing) & Quality \\
\hline $\mathbf{2}$ & Price \\
\hline $\mathbf{4}$ & Advertising \\
\hline $\mathbf{5}$ (Least Influencing) & Reference by relatives, friends \\
\hline
\end{tabular}

Source: Field Survey

It has been seen that while purchasing goods the most important thing that matters to the respondents is the quality of the product followed by the price. However respondents also pay attention to advertising factor whereas packaging matters them the least.

Table 3:

\section{Ranks}

\begin{tabular}{|llllll|}
\hline Celebrity & $\mathbf{1}$ & $\mathbf{2}$ & $\mathbf{3}$ & $\mathbf{4}$ & $\mathbf{5}$ \\
\hline Film stars & $78 \%$ & $17 \%$ & - & $5 \%$ & - \\
\hline Sports star & $2 \%$ & $12 \%$ & $27 \%$ & $12 \%$ & $47 \%$ \\
\hline Singers & $10 \%$ & $30 \%$ & $13 \%$ & $34 \%$ & $13 \%$ \\
\hline Fashion models & $5 \%$ & $27 \%$ & $12 \%$ & $31 \%$ & $27 \%$ \\
\hline Daily Soaps Stars & $5 \%$ & $15 \%$ & $48 \%$ & $20 \%$ & $12 \%$ \\
\hline
\end{tabular}

Table 4:

\begin{tabular}{|ll|}
\hline Ranks & Celebrity \\
\hline $\mathbf{1}$ & Film Stars \\
$\mathbf{2}$ & Singers \\
$\mathbf{3}$ & Daily Soap Stars \\
$\mathbf{5}$ & Fashion Models \\
\hline
\end{tabular}

The above table represents that most of the respondents have ranked film stars as the most persuading celebrity as compared to the sports person who have been ranked as least preferred by majority of the respondents. Respondents find film stars as more appealing rather than sports stars.

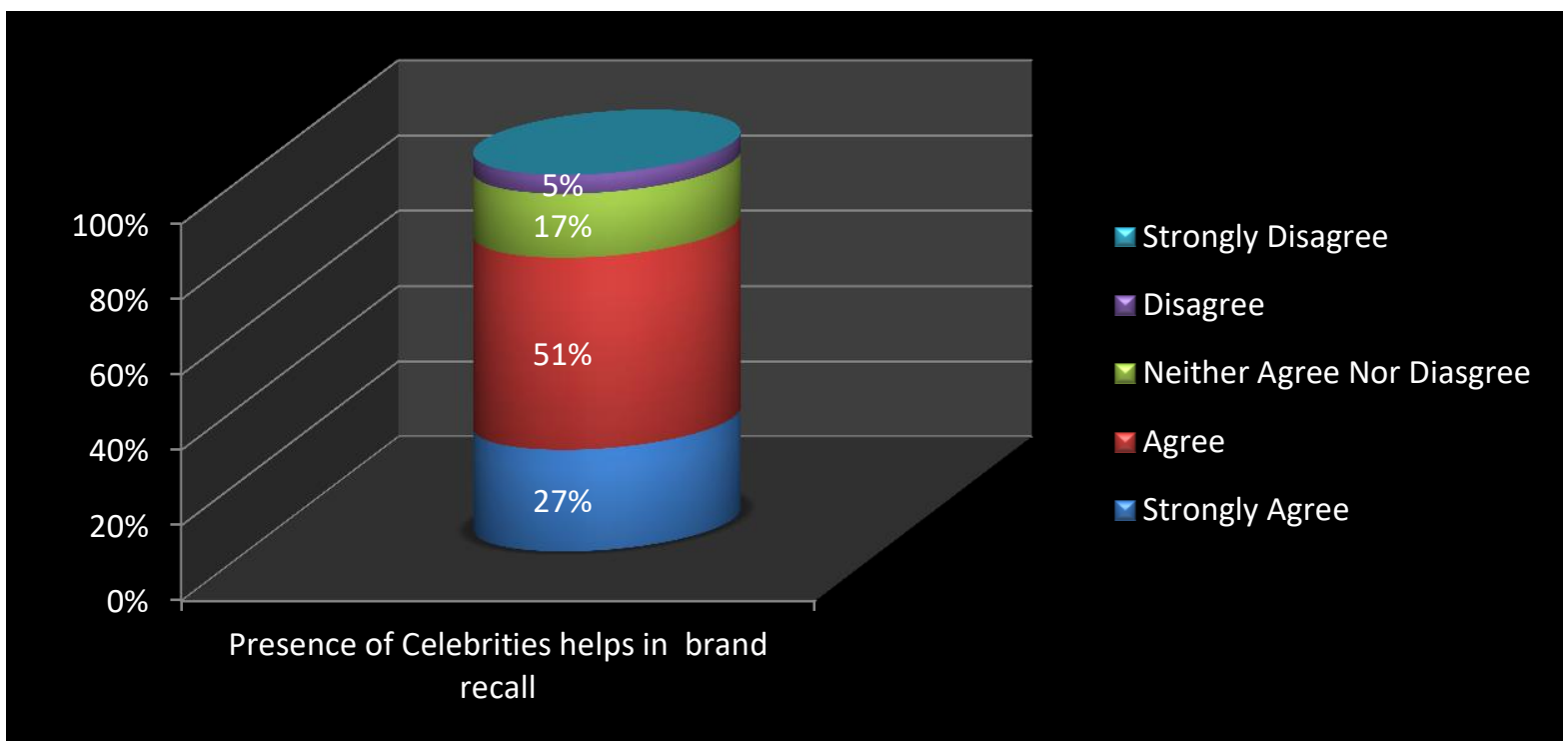

Source: Field Survey

Figure 3: 
The above data shows that most of the students believe celebrities helps increasing the brand recall rate and helps in recognition of the brand. There are around $51 \%$ of the respondents who agree that celebrities' help in brand recognition and $27 \%$ strongly agree about the same whereas only $5 \%$ disagree that celebrities helps in brand recognition and recall.

Table 5:

\begin{tabular}{|c|c|c|}
\hline Favourite Celebrity & $\begin{array}{l}\text { Frequency (Highest Five } \\
\text { Frequency of } 41 \text { respondents) }\end{array}$ & $\begin{array}{l}\text { Most recalled campaigns of the said } \\
\text { celebrities }\end{array}$ \\
\hline Salman Khan & 24 & Thumsup, Wheel, Suzuki Hayate \\
\hline Kareena Kapoor & 17 & Head \& Shoulder, Lakme eyeconic \\
\hline Amitabh Bachchan & 16 & Boroplus, Kalyan Jewellers, Maggie \\
\hline Virat Kohli & 13 & Clean \& Clear, Vicks \\
\hline Alia Bhatt & 11 & Maybelline, Caprese, Garnier \\
\hline
\end{tabular}

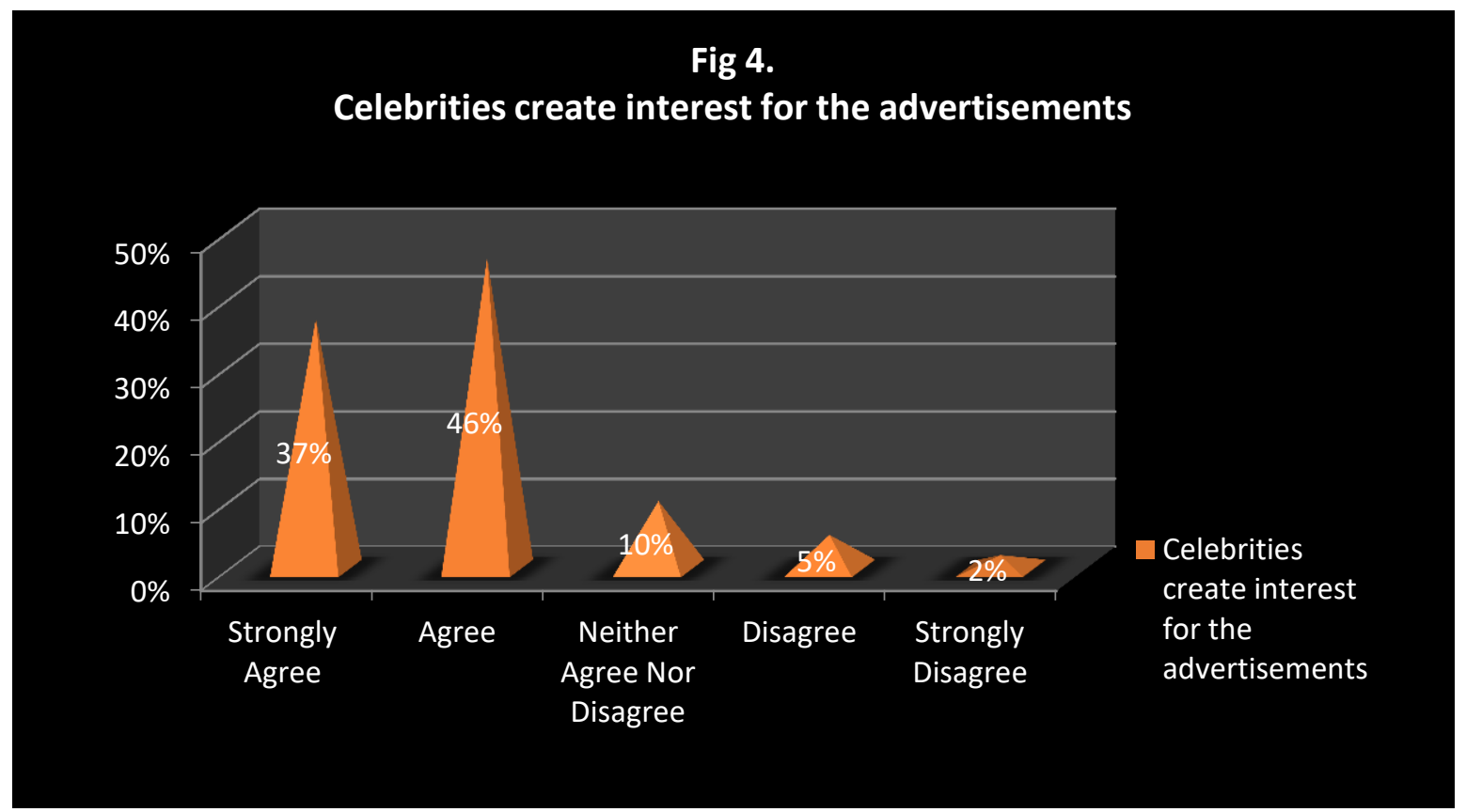

Source: Field Survey

Figure 4:

It can be analyzed from the above data that for $46 \%$ of the respondent's celebrities strongly arouse interest in the advertisements whereas $37 \%$ of the respondents agree that celebrities create interest in the advertisement and only 5\% disagree regards the same. It has been inferred while personal investigation that the young girls find presence of celebrities as an extra factor creating desire for the brand endorsed, many of the girls have also mentioned about the specific ad campaigns where they feel that they watch that particular ad only because of a specific celebrity being involved. (Amitabh Bachchan and Kalyan Jewellers) 


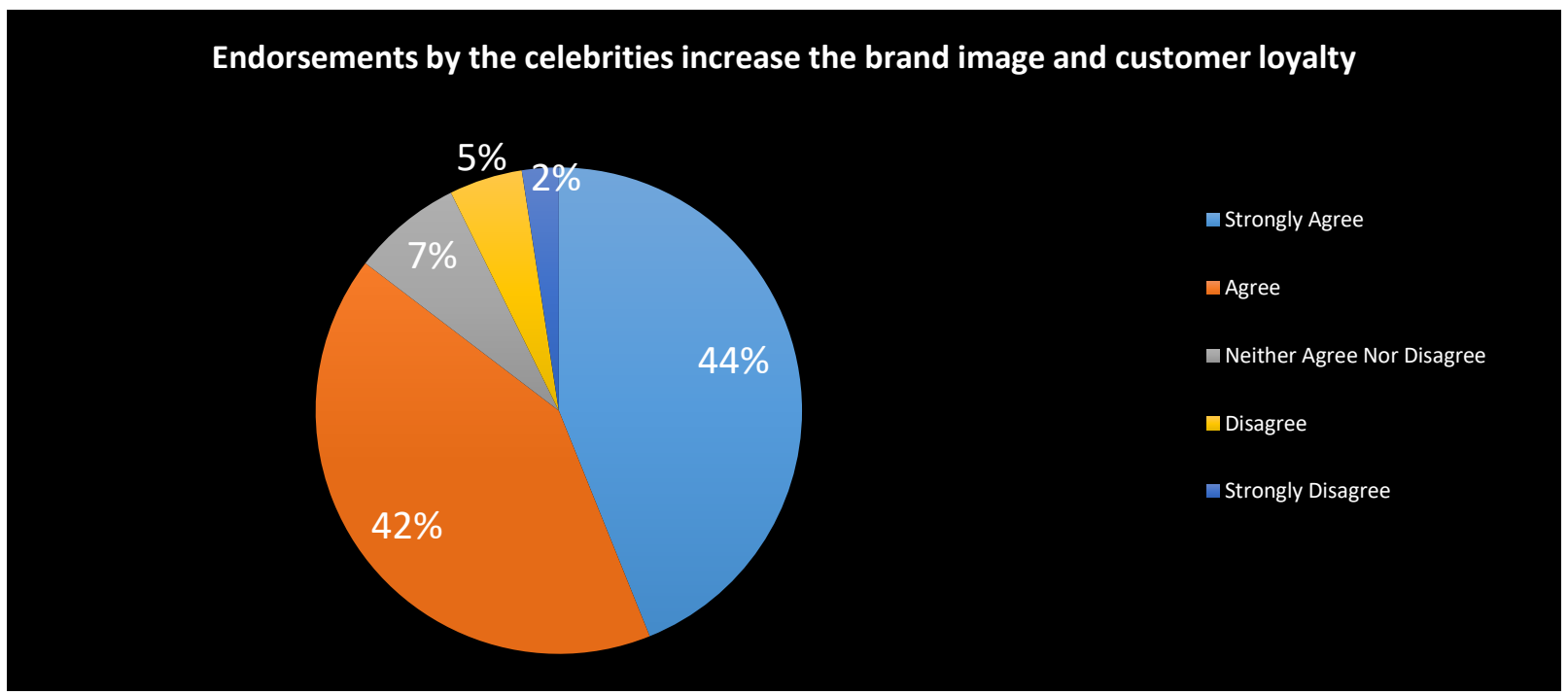

Source: Field Survey

Figure 5:

It can be inferred from the above shown pie chart that around $44 \%$ of the respondents strongly agree that endorsement of brands by the celebrity increase the brand image and customer loyalty thereby built up the trust and credibility in the brand whereas only 5\% of the respondents disagree that celebrities increase the brand image.

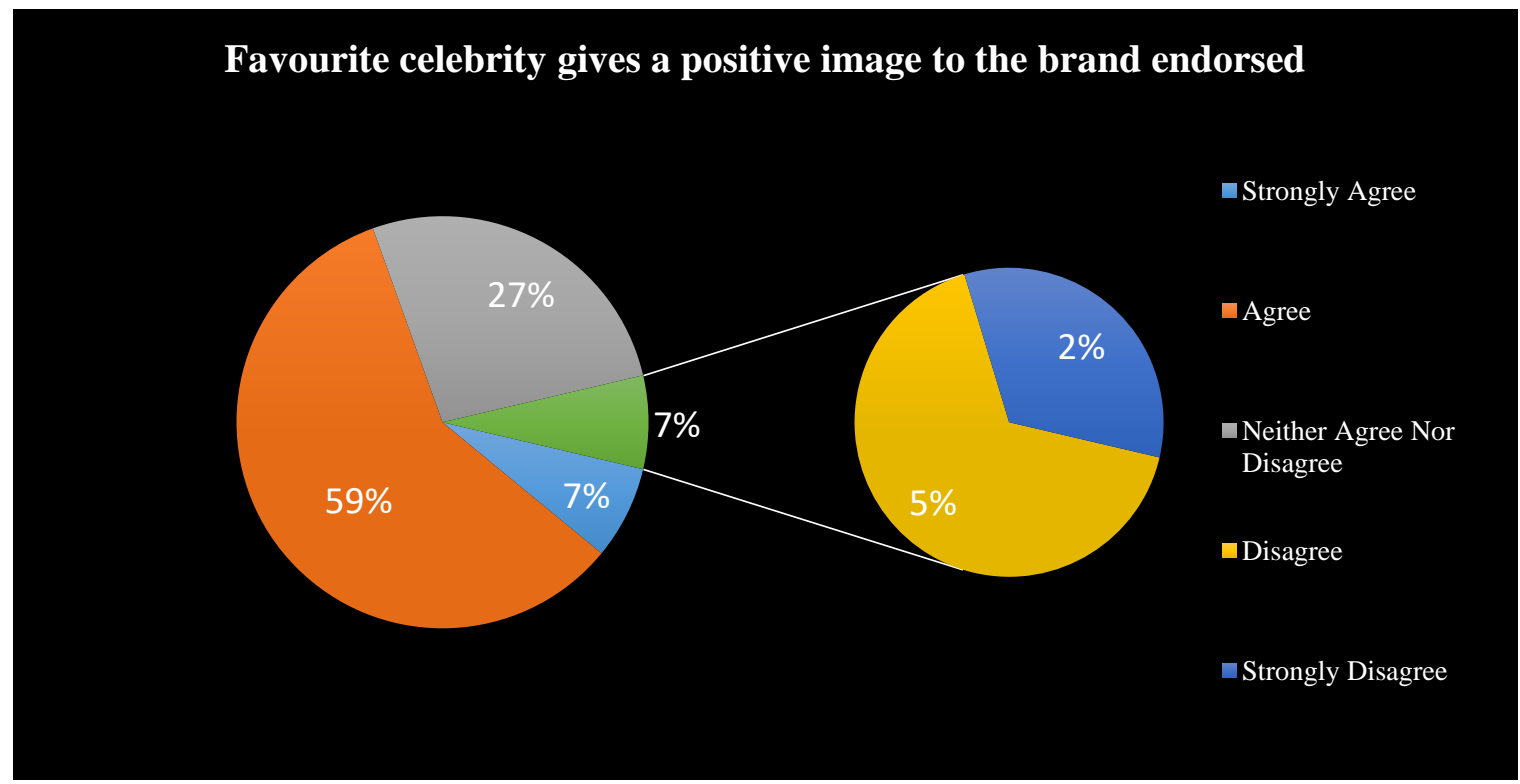

Figure 6:

Source: Field Survey

The above diagram shows that around $60 \%$ of the students agree that their favourite celebrity gives a positive image to the brand endorsed. They believe that if their favourite celebrity would endorse the brand then it would enhance the image of the brand in a positive image and only $7 \%$ of the respondents disagree about the same. 


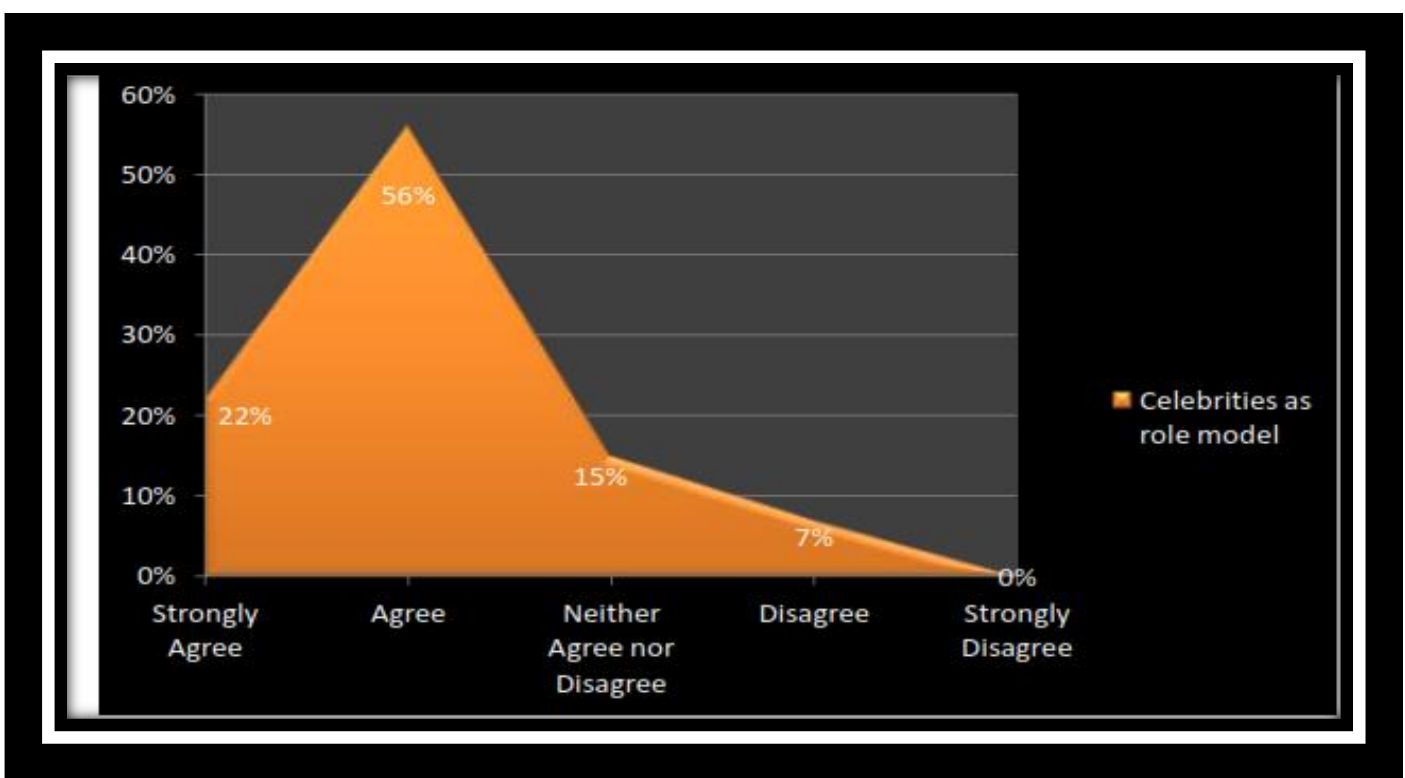

Figure 7: Celebrity as role model influences purchasing decision

Source: Field Survey

The above graph shows that around $56 \%$ of the respondents agree that celebrities as role model do impact their decisions while purchasing a product whereas only around $7 \%$ believe that celebrities as role model do not impact their decisions. It shows that celebrities as role model do impact the purchasing decisions.

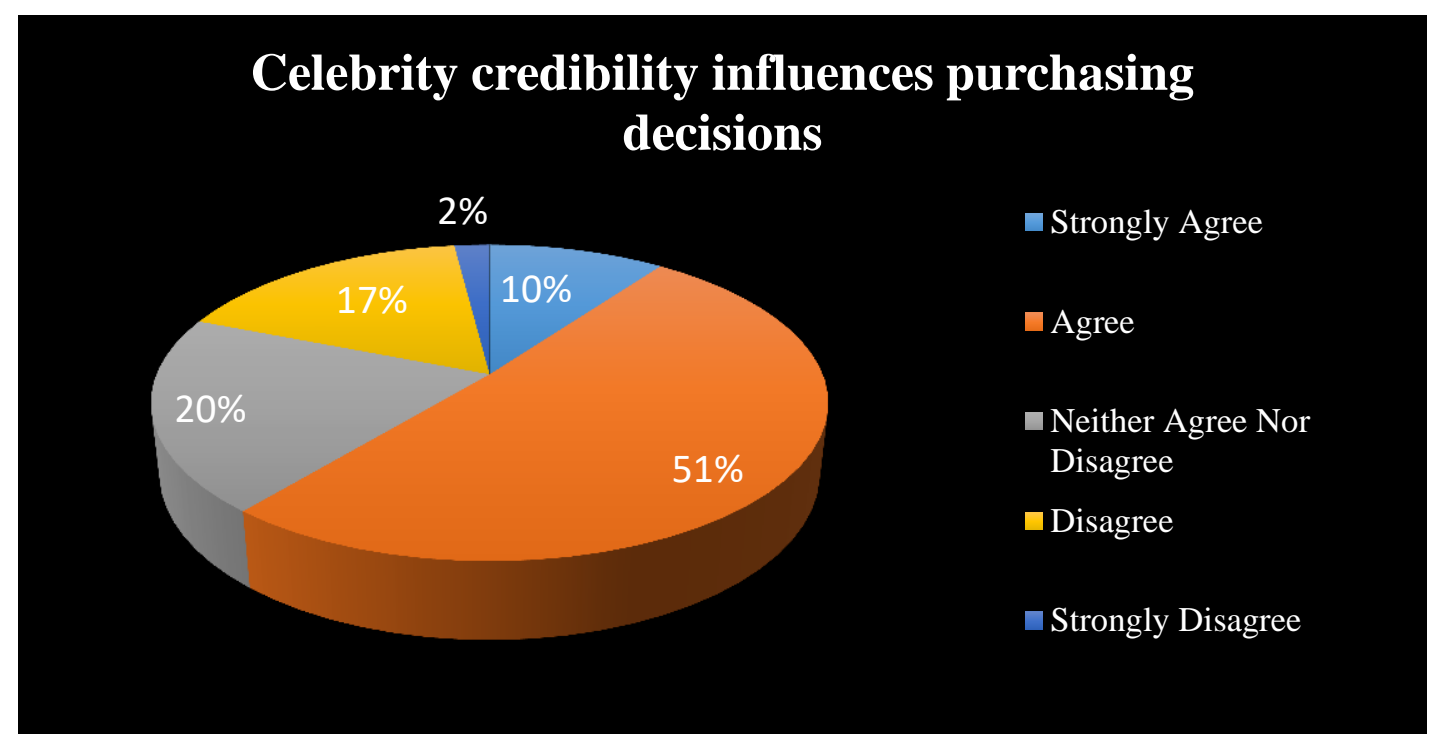

Source: Field Survey

Figure 8:

This pie chart represents that celebrity credibility to a wider extent does impact a consumer's buying behaviour. More than $51 \%$ of the respondents have said that brand endorsed by a celebrity is of good quality and thus it influences more as compared to the non-celebrity endorsed brand. Respondents associate the product with the credibility of the celebrity to a larger extent. 


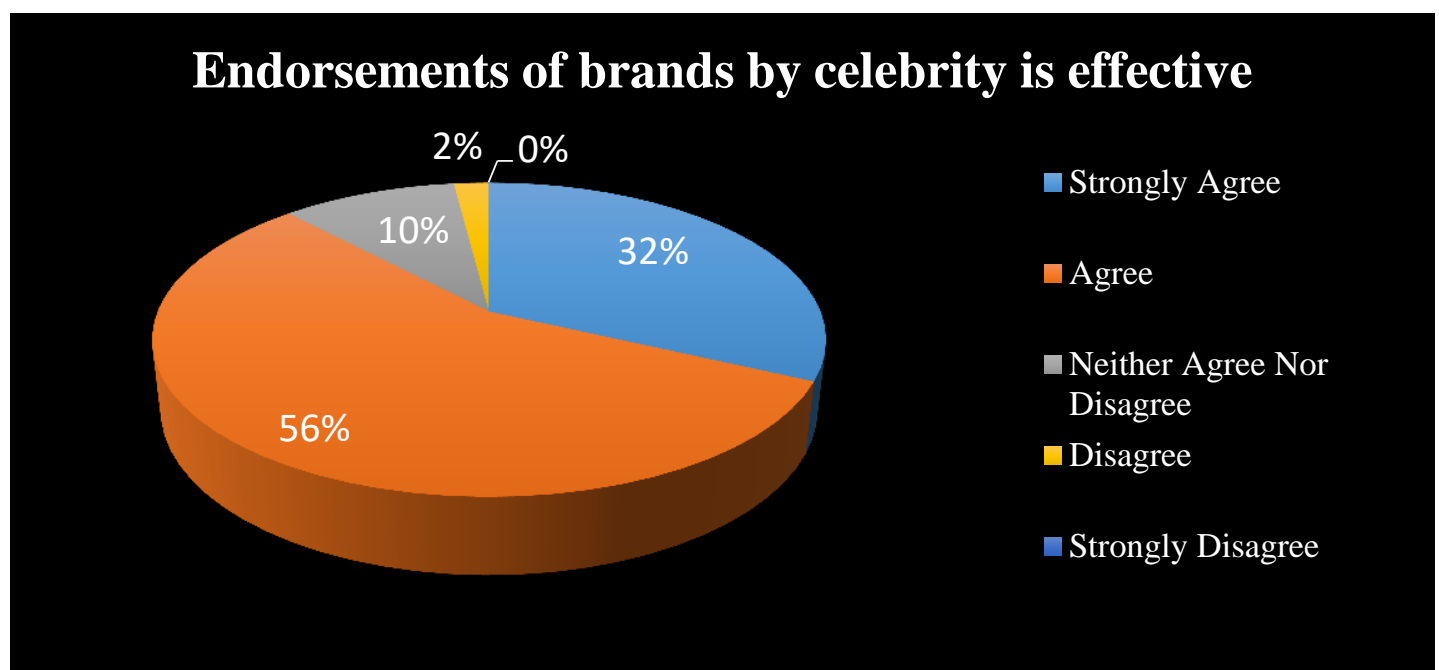

Source: Field Survey

Figure 9:

The above diagram represents around $56 \%$ of the respondents believe that endorsements of brand by celebrities is effective whereas only $2 \%$ believe that celebrity endorsement is ineffective this shows that for majority of the students celebrities act as an influencing factor in the advertisements. Celebrity endorsement is effective according to the viewpoint of the majority of the respondents. Respondents have also mentioned that celebrities though increasing the cost of product but also ensure quality of the product. Respondents have also associated the effectiveness of the celebrity with celebrity credibility.

Table 10:

\section{Required attributes of an effective celebrity Percentage of respondents (\%) believing} Endorsers

Celebrity Popularity

Celebrity Physical Attractiveness

Celebrity should be brand user

Celebrity Availability

Cost of acquiring the celebrity

Celebrities previous endorsement

Celebrity Credibility

Multiple endorsements
100

93

78

66

59

49

44

34

Source: Field Survey

\section{SOME INSTANCES}

Celebrity endorsements enhance product recall and thereby directly increase sales of a product. It can be seen from the following cases:

- Nike roped in tiger woods' at a whooping price for endorsement of its brands. It was observed that sales of golf balls waxed with the celebrity presence in the ad campaign. From 2000 to 2010, the Nike golf ball division reaped an additional profit of \$103 million 
through the acquisition of 9.9 million in sales from Tiger Woods' endorsement effect. Moreover, having Tiger Woods' endorsement led to a price premium of roughly $2.5 \%$. As a result, approximately 57\% of Nike's investment in Woods' $\$ 181$ million endorsement deal was recovered just in U.S. golf ball sales alone. In the case of golf ball, three mechanisms were identified by which these endorsements produced additional profit: golfers switch brands to buy the one endorsed by the player currently leading the rankings; excitement over the leading player generates new sales that would not have otherwise occurred; and the company endorsed by the top player is able to command a price premium, leading competitors to cut prices.

- In 2012 Pepsico's slice was facing a sluggish growth with only 5\% share in the $22 \%$ mango drink category. It became active about increasing the consumption. In a research, Slice found that nothing was more important for Indian consumers than getting a girl's phone number and if the idea was combined with the brand ambassador Katrina's number, it could be a lucrative offer. So, therefore firm decided to rope in Katrina Kaif as brand ambassador, With an 80 per cent mobile phone penetration in the country, giving away Katrina's number became the anchoring insight for Slice communication. Slice launched the campaign 'Katrina ka number, crown ke under" to turn its fortunes around. The campaign made consumers chase Katrina's number even after the campaign was over. The continuous sale of Slice bottles resulted in a growth of 225 per cent with 25 per cent increase in the frequency of consumption and 3 per cent increase in returnable glass bottle share. Adding to the success of the campaign were the 2 million calls that were received. So, by luring consumers with Katrina's number, Slice could get the growth numbers it was looking for.(retrieved from http://pitchonnet.com)

\section{FINDINGS}

1) Celebrity endorsement enhances product information and creates awareness among Consumers. It helps them to recall the brands of the endorsed products.

2) It was revealed that among the various media vehicles TV is the most influencing media persuading consumers to buy the products.

3) The purchase attitude is more strongly influenced by the Quality of the products rather than endorsement factors, price of the product, Discounts and offers etc

4) Film stars are playing major role in creating an impact than Sports personalities.

5) A good number of respondents believe that the products advertised by celebrities are of good quality.

\section{SUGGESTIONS}

1) Celebrity endorsements will be more effective when the ad execution is simple, clean and free of irrelevant design elements and the ad characterizes catchy themes associated with the personality of the celebrity.

2) Celebrity endorsements will be more effective when using a celebrity who is not already strongly associated with another product or service.

3) Celebrity endorsements will be more effective when there are not frequent changes in celebrities who are endorsing the products because that would further enhance the recall ability of the brand. 


\section{CONCLUSION}

The present study has tried to explore the viewpoints of the students in order to assess whether the skyrocketing amounts spent on these celebrities are worthful. It has been revealed during the study that whooping amounts being paid by the marketers to these celebrities are some where influential. The results show that students are being affected by the presence of celebrities. Celebrities to a vast extent impacts a person's purchasing decision, it helps in brand recognition, brand recall and building up the image of the product. It is believed that products endorsed by the celebrities are of good quality also the case studies presented in the paper supports the results drawn. Endorsements can be more effective if celebrities themselves assure that they are using the brand they endorse and thereby assure about the genuineness of the product.

\section{REFERENCES}

[1] Pugazhenthi, A.(2014)," Study on the influence of celebrity endorsement over the perception and purchase intention of college students"

[2] Patel. Pratik C (2015), "Measuring consumers attitude towards celebrity endorsement with special reference to film stars versus sports stars as celebrity endorsers"

[3] Chung, Y.C.Kevin.; Derdenger, T.P.; and Srinivasan, Kannan. (2013), "Economic value of Celebrity Endorsements: Tiger woods' Impact on Sales of Nike golf balls”, Vol.32, No.2, March, pp.271-293.

[4] Jain, Vipul. (2011), "Celebrity endorsement and its impact on sales-A Research Analysis carried out in India”, Global journal of management and business research, Vol.11, No.4, March, pp.68-84.

[5] Mukherjee, Debiprasad. (2009), "Impact of Celebrity Endorsements on brand image”, ssrn.

[6] Randhawa, Anmol.; and Khan, J.Ahmed.(2014), "Impact of celebrity endorsement on consumer buying behaviour”, International journal of business management, Vol.1, No.2, pp.170-188.

[7] http://archive.financialexpress.com/news/whycelebritiesinindiahaverunawaysuccesswithb randendorsements

[8] http://www.exchange4media.com/advertising/whowinsmangowarsfrootimaazaorslice

[9] http://www.4psbusinessandmarketing.com

[10] http://opendorse.com/blog/highestpaidathleteendorsers

[11] http://timescelebex.com

[12] http://www.nielsen.com/us/en/insights/news/2015/theyreallylikemethemostlikedcelebritye ndorsers

[13] http://forbesindia.com

[14] www.tamindia.com

[15] http://zeenews.india.com/sports/cricket/msdhoniis9thmostmarketableathleteinworldbeatsr onaldomessi

[16] http://pitchonnet.com/blog/author/gunjanverma

[17] www.ranker.com 